\title{
Developmental and hormonal regulation of progesterone receptor A-form expression in female mouse lung in vivo: interaction with glucocorticoid receptors
}

\author{
Ruijin Shao, Emil Egecioglu, Birgitta Weijdegård, Karin Ljungström, Charlotte Ling ${ }^{1}$, \\ Julia Fernandez-Rodriguez ${ }^{2}$ and Håkan Billig \\ Department of Physiology/Endocrinology, Institute of Neuroscience and Physiology, The Sahlgrenska Academy at Göteborg University, SE-40530 Göteborg, \\ Sweden \\ ${ }^{1}$ Department of Endocrinology, Wallenberg Laboratory, University Hospital MAS, Lund University, SE-20502 Malmö, Sweden \\ ${ }^{2}$ Swegene Centre for Cellular Imaging, Göteborg University, SE-41390 Göteborg, Sweden \\ (Requests for offprints should be addressed to R Shao; Email: ruijin.shao@fysiologi.gu.se)
}

\begin{abstract}
Progesterone $\left(\mathrm{P}_{4}\right)$ regulates many aspects of physiological functions via two nuclear $\mathrm{P}_{4}$ receptors (PR), PRA and $\mathrm{PRB}$, which are members of a structurally related nuclear hormone receptor superfamily that includes glucocorticoid receptors (GR). The regulation and cellular distribution of PR protein isoforms have been extensively studied in reproductive tissues, but this is not the case in the lung. In the present study, reverse transcriptase (RT)-PCR, Western blotting, and immunolocalization supported the presence of PRA in the lung of female mice, with PRA protein levels significantly increased between postnatal day 7 and 12 , declined at postnatal day 26, and minimal in adults when compared to postnatal day 2. The peak was temporally related to postnatal lung maturation in rodents. Immunoreactivity for PR was detected in the alveolar and bronchial epithelia. We then extended this study to examine, for the first time, the regulation of PRA protein expression in female mouse lung in vivo. Neither the increase in endogenous $\mathrm{P}_{4}$ nor treatment with exogenous $\mathrm{P}_{4}$ regulated PRA protein expression in female mouse lung. However,
\end{abstract}

treatment of mice with the GR/PR antagonist RU 486, but not Org 31710 (a specific PR antagonist), significantly increased PRA protein expression in parallel to a decrease in GR protein expression. In addition, treatment with the synthetic glucocorticoid dexamethasone led to a decrease in PRA protein expression independent of endogenous $\mathrm{P}_{4}$ levels. Furthermore, immunoprecipitation followed by Western blot analysis revealed that, under in vivo conditions, PRA physically interacted with GR in mouse lung. Confocal laser microscopy revealed that PRA and GR co-localized in the nuclei of alveolar epithelia cells, whereas nuclear PR and cytoplasmic GR were detected in bronchial epithelium. Taken together, our observations suggest that PRA may be an important physiological factor involved in postnatal lung development and that the regulation of PRA protein expression is not dependent on $\mathrm{P}_{4}$, but rather on functional glucocorticoid/GR signaling mediated by protein-protein interaction in the mouse lung.

Journal of Endocrinology (2006) 190, 857-870

\section{Introduction}

Progesterone $\left(\mathrm{P}_{4}\right)$, an ovarian steroid hormone, exerts diverse functions in several physiological processes ranging from female reproduction to brain and bone cell metabolism (Graham \& Clarke 1997). In many cases, the cellular actions of this hormone are mediated primarily by the nuclear $\mathrm{P}_{4}$ receptors (PR), including two well-studied isoforms, PRA and PRB (Kastner et al. 1990a). Both isoforms function as hormone-activated transcription factors and are involved in the regulation of gene expression during development, growth, and differentiation in target organs (Graham \& Clarke 1997, Shao et al. 2003, 2006). In addition, the human placenta and myometrial cells express high levels of non-nuclear PR isoform, truncated PRC (Condon et al. 2006, Taylor et al. 2006). The roles of specific PRC in the steroid hormonal regulation and the importance of PRC gene expression are not clear. In the absence of $\mathrm{P}_{4}$, the $\mathrm{PR}$ isoforms are maintained as a part of an inactive multiprotein complex that consists of the receptor and regulatory heat shock protein in the nuclei of target cells (Smith et al. 1990). When $\mathrm{P}_{4}$ binds to $\mathrm{PR}$, the receptors dissociate from heat shock proteins, undergo a change in conformation, dimerize, and are hyperphosphorylated, leading to the initiation of transcriptional regulation (Mohamed et al. 1994, McDonnell 1995). PRA lacks 164 amino acids at the N-terminus compared to the full-length PRB. The two isoforms arise from either transcription from alternative promoters (Kastner et al. 1990a,1990b), or translation 
from alternative sites in the same mRNA (Conneely et al. 1987, Giangrande \& McDonnell 1999). The relative expression of the two PR isoforms is conserved in rodents and humans (Schneider et al. 1991, Kraus et al. 1993, Giangrande \& McDonnell 1999), but varies dramatically between different tissues, cell types, physiological, and disease states, and is under developmental control (Ilenchuk \& Walters 1987, Schneider et al. 1991, Graham \& Clarke 1997, Bethea \& Widmann 1998). Although both isoforms have similar hormone- and DNA-binding affinities, and form homo- and/or hetero-dimers (Lessey et al. 1983, Kastner et al. 1990a), several in vitro studies have shown that PRA and PRB display different transcriptional effects on progestin-responsive promoters in a cell- and promoter contextdependent manner (Vegeto et al. 1993, Wen et al. 1994, Giangrande \& McDonnell 1999). For instance, PRA is often transcriptionally inactive and acts as a potent dominant repressor of PRB-mediated transcription (Tung et al. 1993). Furthermore, PRA has been found to diminish the activities of other nuclear receptors such as the glucocorticoid receptor (GR) under some conditions (Vegeto et al. 1993), whereas PRB is shown to activate transcription in several target tissues (McDonnell \& Goldman 1994, McDonnell et al. 1994, Wen et al. 1994). Recently, studies in PR knockout mice confirmed that the two isoforms are not functionally equivalent and even imply tissue-selective isoform activity in vivo (Curtis \& Korach 2000, Mulac-Jericevic et al. 2000). Thus, it is conceivable that the differential expression of $\mathrm{PR}$ protein isoforms in certain target tissues may influence the action of $\mathrm{P}_{4}$. Several studies have demonstrated the potential for differential steroid receptor interactions at the level of transcription in numerous cell lines and tissue types in vitro (Uht et al. 1997, Kinyamu \& Archer 2003). However, much less work has been done on the interaction between $\mathrm{PR}$ and other steroid receptors in vivo.

Although previous data suggest that $\mathrm{P}_{4}$ might be important in lung physiology and diseases (e.g. asthma and cancer) (Milne 1979, Haggerty et al. 2003, Ishibashi et al. 2005), the regulation and cellular distribution of $\mathrm{PR}$ protein isoforms in lung remain largely unknown. Previous studies have shown that PR mRNAs and proteins are found in rabbit (Giannopoulos et al. 1982, Bullock et al. 1987, Nielsen et al. 1987, Camacho-Arroyo et al. 1994, 1998), rodent (Moser \& Daxenbichler 1982, Beyer et al. 2003), and chicken (Pasanen et al. 1997) lungs. In the present study, we sought to initially establish the presence of PR isoforms in mouse lung using reverse transcriptase (RT)-PCR and Western blotting analyses and on finding that PRA mRNA and protein were specifically expressed in mouse lung, we examined the possibility of regulation of PRA protein expression in mice during postnatal growth and development. It is generally accepted that $\mathrm{P}_{4}$ 's actions on target tissues are mediated primarily by binding to its cognate nuclear receptors. Therefore, we examined the steroid hormone regulation of PRA protein expression in female mouse lung by different experimental approaches, including treatment with gonadotropins, $\mathrm{P}_{4}$, dexamethasone, and $\mathrm{PR}$ and/or GR antagonists. Furthermore, we investigated whether under in vivo conditions, PRA physically interacted with GR in mouse lung by using immunoprecipitation followed by Western blot and double-immunofluorescent assays.

\section{Materials and Methods}

\section{Hormones and chemicals}

Equine gonadotropin (eCG), dexamethasone, monoclonal anti- $\beta$-actin, and alkaline phosphatase-conjugated goat-antimouse immunoglobulin were obtained from Sigma. Human chorionic gonadotropin (hCG) and the specific PR-antagonist Org 31710 (Kloosterboer et al. 1994) were provided by $\mathrm{N}$ V Organon (Oss, Holland). The PR/GR antagonist RU486 (Cadepond et al. 1997) was provided by Exelgyn (Paris, France). Rabbit polyclonal anti-PR (c-19 and c-20) and their respective blocking peptides (c-19p and $c-20 p)$, as well as mouse monoclonal anti-GR were obtained from Santa Cruz Biotechnologies, Inc. (Santa Cruz, CA, USA). Mouse monoclonal anti-PRB (Joensuu et al. 1990) was obtained from Affinity BioReagents, Inc. (ABR, Golden, CO, USA). Mouse monoclonal anti-proliferating cell nuclear antigen (PCNA) was obtained from Novocastra Laboratories Ltd (Newcastle upon Tyne, UK). Normal rabbit serum and normal goat serum were obtained from DAKO Corp. (Carpinteria, CA, USA). Alkaline phosphatase conjugated goat-anti-rabbit immunoglobulin was obtained from Tropix (Bedford, MA, USA). Biotin-SP-conjugated donkey antirabbit IgG, fluorescein (DTAF)-conjugated streptavidin, and Cy 3-conjugated donkey anti-mouse IgG were purchased from Jackson ImmunoResearch Laboratories, Inc. (West Grove, PA, USA). All other chemicals were purchased from Merck, unless otherwise specified.

\section{Animals and experimental design}

Timed pregnant female mice (C57BL/6) were purchased from Taconic M\&B, Copenhagen, Denmark. They were monitored daily between 0900 and $0930 \mathrm{~h}$ for delivery of pups and the day of birth was defined as postnatal day (PND) 0. Pups were sexed according to ano-genital distance and male pups were removed. All animals were housed and acclimatized to controlled temperature $\left(21 \pm 2{ }^{\circ} \mathrm{C}\right)$ and with a ratio of $12 \mathrm{~h}$ light: $12 \mathrm{~h}$ darkness cycles, with the standard rodent chow and tap water ad libitum. The animal studies were reviewed and approved by the ethics committee at Göteborg University, Sweden. At least five animals in each group were used for every experimental approach unless otherwise specified.

Experiment 1 This experiment was designed to determine the presence of the two PR isoforms (PRA and PRB) in mouse lung. Mice were killed following deep anesthetization with pentobarbitone sodium and selected whole tissues (lung, liver, fallopian tube, and uterus) were carefully removed and 
lung tissue was frozen in liquid nitrogen for subsequent Western blot or RT-PCR analysis.

Experiment 2 This experiment was designed to examine the regulation and cellular localization of PRA protein expression in female mouse lung during postnatal growth and development. Female mice were deeply anesthetized with pentobarbitone sodium at various time intervals (PND 2, 7, 12, 26, and 90) between 0800 and $1000 \mathrm{~h}$, whole lung tissue isolated from three mice at each time point were quickly dissected and either frozen in liquid nitrogen or stored at $-135^{\circ} \mathrm{C}$, or fixed in $4 \%$ formaldehyde in neutral buffer (Sigma) for $24 \mathrm{~h}$ at $4{ }^{\circ} \mathrm{C}$ and embedded in paraffin wax for either Western blot or immunohistochemical analysis.

Experiment 3 This experiment was designed to examine the effects of endogenous or exogenous $\mathrm{P}_{4}$ on regulation of PRA protein expression in female mouse lung. In our experiments, sequential administration of eCG and hCG is substituted for effects of follicle-stimulating hormone and luteinizing hormones in vivo. This in vivo model has been used for induction of ovarian $\mathrm{P}_{4}$ production and further elevates serum $\mathrm{P}_{4}$ levels in female mice in vivo (Shao et al. 2003, 2006). Female mice (PND 26) were given a single injection of eCG (5 IU, i.p.) followed by treatment with hCG (5 IU i.p.) after 48 h. Six hours after hCG treatment, mice were killed by approved methods and tissues were dissected. To determine the specific effect of $\mathrm{P}_{4}$ on regulation of $\mathrm{PR}$ protein expression, female mice (PND 26) were randomly selected and received a single i.p. injection of $\mathrm{P}_{4}$ ( $4 \mathrm{mg} / \mathrm{kg}$ per body weight in $100 \mu \mathrm{l}$ sesame oil). A single pharmacological dose of $\mathrm{P}_{4}$ was chosen on the basis of previous studies (Russo et al. 2001, Shao et al. 2006). Lung tissue was obtained at different time intervals $(6,24,36,48$, and $72 \mathrm{~h})$ for Western blot analysis.

Experiment 4 This experiment was designed to examine the effects of PR/GR antagonist RU 486 and PR antagonist Org 31710 on the regulation of PRA and GR protein expression in female mouse lung. Thirty female mice (PND 26), chosen at random, received eCG (5 IU, i.p.). The animals were then randomly divided into six groups of five mice for each group. Mice in the first two groups were given either $2 \mathrm{mg}$ of RU 486 or $1 \mathrm{mg}$ Org 31710 in $100 \mu \mathrm{l}$ sesame oil by i.p. injection after treatment with eCG for $44 \mathrm{~h}$. Mice in the remaining groups were injected with either $100 \mu \mathrm{l}$ sesame oil (two groups, as controls), $2 \mathrm{mg}$ RU 486 or $1 \mathrm{mg}$ Org 31710 dissolved in $100 \mu \mathrm{l}$ sesame oil after treatment with eCG for $48 \mathrm{~h}$. All mice in the three groups received hCG (5 IU, i.p.) at $48 \mathrm{~h}$ after eCG treatment. Six hours after hCG treatment, the mice were killed by approved methods. Lung tissue was frozen in liquid nitrogen for subsequent Western blot analysis.

Experiment 5 This experiment was designed to study the effect of glucocorticoids on the regulation of PRA and GR expression in female mouse lung. Female mice (PND 26) were treated with gonadotropins and/or dexamethasone, as described in Experiments 3 and 4. Animals were given a single i.p. injection of dexamethasone $(600 \mu \mathrm{g} / \mathrm{kg}$ per body weight) dissolved in saline, chosen on the basis of a previous study (Russo et al. 2001). Mice were killed by approved methods, lung tissues removed and frozen in liquid nitrogen for Western blot analysis.

\section{RT-PCR}

Total RNA was isolated from individual tissues using Trizol Reagent (Life Technologies) according to the manufacturer's instructions. The quantity of extracted RNA was determined by spectrophotometry. Any contaminating genomic DNA was digested by RNase-free DNase. cDNA was reversely transcribed from $5 \mu \mathrm{g}$ total RNA using $0 \cdot 25 \mu \mathrm{g}$ random hexamer (Life Technologies) in $20 \mu \mathrm{l}$ of a $1 \times$ AMV-RT buffer containing $9 \mathrm{U}$ AMV-RT (Invitrogen), $39 \mathrm{U}$ ribonuclease inhibitor (RNasin) (Promega), and $4 \mu \mathrm{l} 5 \mathrm{mM}$ deoxyNTP (dNTP) mixtures (Amersham). Reactions were incubated for $1 \mathrm{~h}$ at $42{ }^{\circ} \mathrm{C}$, heated to $95^{\circ} \mathrm{C}$ for $5 \mathrm{~min}$ and then chilled on ice. An aliquot $(5 \mu \mathrm{l})$ of RT product was used for PCR amplification in a total volume of $50 \mu \mathrm{l}$ PCR-buffer presented with $2 \cdot 5 \mathrm{U}$ TaqDNA polymerase (Promega), $2 \mu \mathrm{l} \mathrm{mM}$ dNTP mixtures and the appropriate primer pairs as mentioned below. The PCR consisted of a denaturing step at $94^{\circ} \mathrm{C}$ for $5 \mathrm{~min}$. The thermal cycle profile used in this study was (1) denaturing at $94^{\circ} \mathrm{C}$ for $30 \mathrm{~s}$, (2) annealing the primers at $55^{\circ} \mathrm{C}$ for $30 \mathrm{~s}$, (3) extending the primers at $72{ }^{\circ} \mathrm{C}$ for $2 \mathrm{~min}$. After the final amplification, the reaction was elongated for an additional $7 \mathrm{~min}$ at $72{ }^{\circ} \mathrm{C}$. PRA/B and PRB were amplified after 30 or 39 cycles respectively. The amount of cDNA and the number of PCR cycles needed to detect PR were determined in a preliminary experiment. A portion $(10 \mu \mathrm{l})$ of the PCR mixture was electrophoresed in $1 \cdot 2 \%$ agarose gel along with a $100 \mathrm{bp}$ DNA ladder (Life Technologies) and visualized by ethidium bromide staining. Specificity of amplified products was confirmed by including RT control reactions. Ribosomal protein L19 was selected as an internal control to confirm that cDNA had been synthesized and to check for genomic DNA contamination (Chan et al. 1987). PCR was performed using primers specific for mouse PRA/B (sense 5'-GGCAAATCCCACAGGAGTTTG-3', antisense $5^{\prime}$-AGACATCATTTCCGGAAATTC-3'; expected PCR-amplified product size, 327 bp) (Beyer et al. 2002); mouse PRB (sense $5^{\prime}$-ATGACTGAGCTGCAGGCAAAG- $3^{\prime}$, antisense $5^{\prime}$-CTTCTACCCCAGAGAAAGCGC-3'; expected PCR-amplified product size, $277 \mathrm{bp}$ ) (Beyer et al. 2002); ribosomal protein L19 (sense 5'-GAAATCGCCAATGCCAACTC-3', antisense $5^{\prime}$-ACCTTCAGGTACAGGCTGTG-3', 290 bp) (Robker et al. 2000).

\section{Western blot and co-immunoprecipitation analyses}

Protein extraction and Western blotting were performed according to standard methods as described previously in Shao et al. (2003). Equal amounts of protein in the cell extracts were pretreated with $4 \times$ SDS before loading and 
resolved by $4-12 \%$ SDS-polyacrylamide gels (Novex, San Diego, CA, USA) under reducing conditions. The separated samples were electrotransferred to polyvinyldifluoride membranes (Amersham) and treated with blocking buffer $(0 \cdot 2 \%$ I-Block, $0 \cdot 2 \%$ BSA, $5 \mathrm{mM} \mathrm{MgCl}_{2}, 3 \mathrm{mM} \mathrm{NaN}_{3}$, and $0 \cdot 3 \%$ Tween 20 in PBS, pH 7.4) for $2 \mathrm{~h}$. The antibodies used to detect $\mathrm{PR}$ in this study were raised against human PRs and recognized ligand-binding domain (PR c-19) or DNAbinding domain (PR c-20) of PR in rodent tissues by Western blotting and immunohistochemical analyses. The membranes were incubated with primary antibody for either anti-PRA/B (c-19+c-20, 1:250), anti-PRB (1:50), anti-PCNA (1:1000), anti- $\beta$-actin $(1: 1000)$, or anti-GR $(1: 500)$ in blocking buffer overnight at $4{ }^{\circ} \mathrm{C}$. After washing in blocking buffer for $2 \mathrm{~h}$, the membranes were incubated with alkaline phosphataselinked secondary antibody (polyclonal secondary antibody at $1: 40000$ or monoclonal secondary antibody at 1:80 000 dilutions respectively) in blocking buffer for $2 \mathrm{~h}$ with gentle shaking and detected using CDP-Star as substrate (Tropix, Bedford, MA, USA). Immunoblotted signals were exposed, developed on ECL-film (Amersham) and subsequently scanned into a computer. Individual bands were quantified directly from membranes by densitometry using ImageQuant (version 5.0) software program (Molecular Dynamics, Inc., Sunnyvale, CA, USA). Equal protein loading was determined by the expression of $\beta$-actin, as well as confirmed by staining the gels with Coomassie blue after the transfer. As a negative control, the two PR antibodies were pre-absorbed with tenfold excess of neutralizing synthetic PR peptides for $4 \mathrm{~h}$ at room temperature before use to demonstrate antigen specificity.

For co-immunoprecipitation experiments, tissues were extracted with ice-cold lysis buffer $(25 \mathrm{mM}$ Tris- $\mathrm{HCl}$, $\mathrm{pH} 8 \cdot 0,150 \mathrm{mM} \mathrm{NaCl}, 0 \cdot 5 \%$ Nonidet P-40, 1\% SDS, $200 \mu \mathrm{M}$ sodium deoxycholate, $1 \mathrm{mM}$ dithiothreitol (DTT), $5 \mathrm{mM}$ EDTA, $0.5 \mathrm{mM}$ phenylmethylsulphonyl fluoride (PMSF), $10 \mathrm{mM}$ N-ethylmaleimide, $10 \mathrm{mM}$ iodoacetamide, and a cocktail of protease inhibitors (Roche). Either anti-PR or anti-GR antibodies were added to $500 \mu \mathrm{g}$ protein extracts and incubated for $4 \mathrm{~h}$ at room temperature. Immune complexes were obtained by the addition of $50 \mu \mathrm{l}$ Pansorbin cells (Calbiochem, San Diego, CA, USA). The resulting immobilized immune complexes were washed in RIRA buffer $(50 \mathrm{mM}$ Tris- $\mathrm{HCl}, \mathrm{pH} 7 \cdot 8,150 \mathrm{mM} \mathrm{NaCl}, 15 \mathrm{mM}$ $\mathrm{MgCl}_{2}, 0 \cdot 5 \%$ Nonidet P-40, $0 \cdot 3 \%$ Triton X-100, $0 \cdot 5 \%$ sodium deoxycholate, $5 \mathrm{mM}$ EDTA, $1 \mathrm{mM}$ DTT, and a cocktail of protease inhibitors). The bound protein was eluted by boiling in $30 \mu \mathrm{l}$ SDS sample reducing loading buffer (Novex) for $5 \mathrm{~min}$. Immunoprecipitated complexes for either GR or PRA/B were loaded in the same gels, which were run at the same time within the same electrophoresis unit and examined by immunoblotting as described above.

To re-probe the blot with another antibody, the blot was re-hydrated in methanol, rinsed and incubated with stripping buffer $(62.5 \mathrm{mM}$ Tris- $\mathrm{HCl}, 2 \%$ SDS and $100 \mathrm{mM}$ $\beta$-mercaptoethanol, $\mathrm{pH} 6 \cdot 8$ ) at $50{ }^{\circ} \mathrm{C}$ for $30 \mathrm{~min}$.

\section{Immunohistochemistry and microscopy}

PR immunolabeling was undertaken essentially as described previously (Shao et al. 2003, 2006). Paraffin-embedded lung sections were deparaffinized in xylene and rehydrated through graded series of ethanol and water. Antigens were retrieved by $10 \mathrm{mM}$ sodium citrate buffer. After three washes with Trisbuffered saline (TBS $50 \mathrm{mM}$ Tris, $0 \cdot 9 \% \mathrm{NaCl}, \mathrm{pH} 7 \cdot 5$ ), endogenous peroxidase activity was abolished by $3 \%$ hydrogen peroxide in TBS and non-specific binding was blocked by incubating sections in 10\% normal goat serum. Sections were incubated with primary antibodies (anti$\mathrm{PRA} / \mathrm{B}(\mathrm{c}-19+\mathrm{c}-20)$ at $1: 100$, and anti-PRB at 1:50 dilutions respectively) in TBS containing 1\% BSA overnight at $4{ }^{\circ} \mathrm{C}$ in a humidified chamber. After a series of washing with TBS, sections were then stained using the avidinbiotinylated-peroxidase complex detection system (ABC kit, Vector Laboratories, Inc., Burlingame, CA, USA) according to the manufacturer's instructions. Immunostaining was then visualized using 3, 3-diaminobenzidine tetrahydrochloride $\left(0.5 \mathrm{mg} / \mathrm{ml}\right.$ in PBS and $\left.0 \cdot 01 \% \mathrm{H}_{2} \mathrm{O}_{2}, \mathrm{pH} 7 \cdot 6\right)$ for $10 \mathrm{~min}$. Slides were viewed on Nikon E-1000 microscope (Bergström Instruments $\mathrm{AB}$, Stockholm, Sweden) under brightfield optics, and photomicrographed using Easy Image 1 (Bergström Instrument AB, Göteborg, Sweden). To determine the specificity for detection of PR, the primary antibodies (c$19+\mathrm{c}-20,1: 250 \mathrm{each})$ were pre-incubated with tenfold excess of neutralizing synthetic PR peptides $(c-19 p+c-20 p)$ for $4 \mathrm{~h}$ at room temperature. These pre-absorbed antibodies were substituted for primary antibodies, while adjacent sections were incubated with PR primary antibodies alone. Serial sections of lung were examined blind under light microscopy.

Double-immunofluorescent staining of PR and GR was performed according to a previously described procedure (Shao et al. 2004). Sections were incubated with a mixture of antibodies against PR and GR diluted to $1: 100$ and 1:150 respectively, in PBS containing 1\% BSA and 5\% fat-free milk. Each primary antibody was serially diluted to optimize the concentration used to achieve maximum sensitivity and specificity. Immunodetection was accomplished using the species-specific secondary antibodies, either a biotin-conjugated anti-rabbit antibody together with streptavidin conjugated with DTAF or Cy 3-conjugated anti-mouse antibody. Sections were washed and mounted with Fluorescent Mounting Media (DAKO). Slides were viewed on an Axiovert 200 microscope (Zeiss, Jena, Germany) equipped with a laser-scanning confocal imaging LSM 510 META system (Carl Zeiss, Jena, Germany) and photomicrographed. The resulting stain was evaluated blind by three observers. The immunohistochemical figures illustrated are representative of those observed in numerous sections from multiple animals.

Serum $\mathrm{P}_{4}$ assay

Serum $\mathrm{P}_{4}$ concentration was measured by RIA according to a protocol provided by the manufacturer (Perkin-Elmer Life 
and Analytical Sciences, Wallac Oy, Turku, Finland) (Shao et al. 2006). Trunk blood was obtained from cardiac puncture in immature mice treated with or without gonadotropins, PR antagonists, and dexamethasone. All samples were tested as duplicates together in one run. The sensitivity of the assay was typically better than $0.8 \mathrm{nmol} / 1$, and the intra-assay coefficient of variation was $3 \cdot 3-7 \cdot 3 \%$.

\section{Statistical analysis}

Results are presented as the mean \pm S.E.M. Statistical analysis was performed by one-way ANOVA using Analyse-It program (Analyse-It Software, Ltd, Leeds, UK). Significant differences between the treatment groups were determined by the post hoc Tukey's test. Effects were considered to be significant if $P$ value was less than $0 \cdot 05$.

\section{Results}

$P R A$ is the predominant PR in mouse lung

PRA/B mRNA was detected in female mouse lung at PND 7 and 26, whereas PRB transcripts in the same lung tissues were absent (Fig. 1A). In parallel with PCR analysis, we used the same selected tissues for Western blot analysis to demonstrate $\mathrm{PR}$ protein isoform expression, with only PRA protein expression found in mouse lung, at PND 7 and 26 (Fig. 1B). Male mice at PND 26 also displayed similar levels of PRA protein expression in lung (data not shown). Furthermore, we used a specific PRB antibody to confirm this result under PRA/B antibodies, and no PRB immunoreactive band was detected in all lung tissues examined, while expression of PRB was observed in mouse fallopian tube and uterus (Fig. 1C) (Shao et al. 2006).

Developmental regulation of $P R A$ protein expression in female mouse lung

To determine whether PRA protein levels are regulated during postnatal development in female mouse lung, we examined PRA protein expression by Western blot analysis. PRA immunoreactive protein was detected in all lung tissue extracts isolated from female mice of different ages. Levels of PRA protein increased with age, peaking at PND 7, although significantly increased levels of PRA protein were also
A

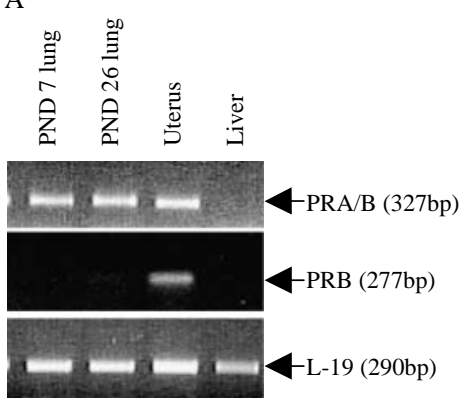

B

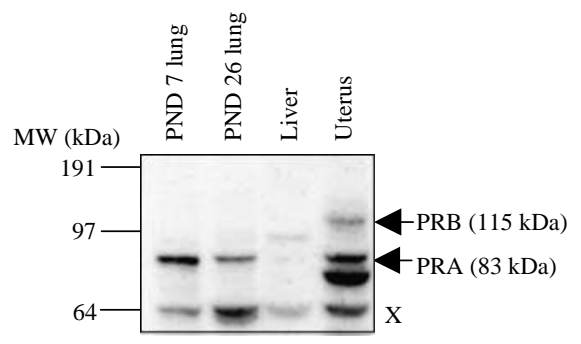

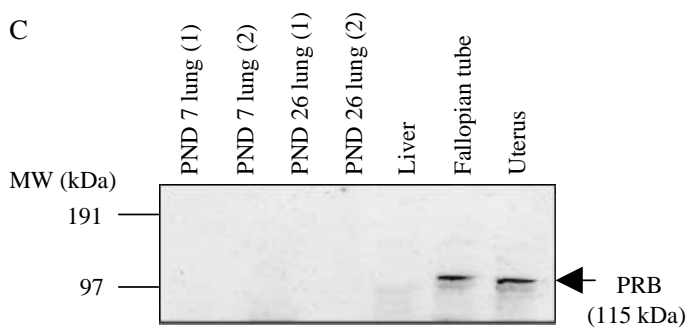

Figure 1 Expression of PR isoforms in mouse lung. (A) Total RNA from the indicated female mouse lungs was reversely transcribed and amplified by PCR with primers specific for mouse PRA and PRB as well as L-19 (as described in Materials and Methods). Amplified products were resolved on $1.5 \%$ agarose gels and visualized by ethidium bromide staining. A mouse uterus-positive control and a mouse liver-negative control were also included. Similar analysis with two different RNA preparations from different animal tissues ( $n=3$ each). This figure is representative of two separate experiments in which same results were obtained. (B) and (C) Protein samples were isolated from mouse lungs and selected tissues ( $n=3$ each). The equal protein ( $50 \mu \mathrm{g} / \mathrm{lane}$ ) underwent Western blot analysis with either anti-PRA/B (B) or anti-PRB antibody as described in Materials and Methods. The immunoblots are representative of duplicate blots of two independent experiments from both female and male mice. The molecular mass markers $(\mathrm{kDa})$ are indicated on the left. $X$ denotes protein band that cross-reacted with neutralizing synthetic PR peptide-PR antibodies. PND, postnatal days. 
detected at PND 12. PRA protein levels declined by PND 26 and were barely detectable in adults (PND 90) compared to PND 2 (Fig. 2A). There is rapid cell proliferation during early- and mid-gestational lung organogenesis (Burri 1997,
Kaplan 2000). At PNDs 2-4, the number of proliferating cells substantially increases to support postnatal growth in mouse lung (Thaete et al. 1989). The PCNA synthesis correlates with the proliferative state of the cell and it represents a key
A
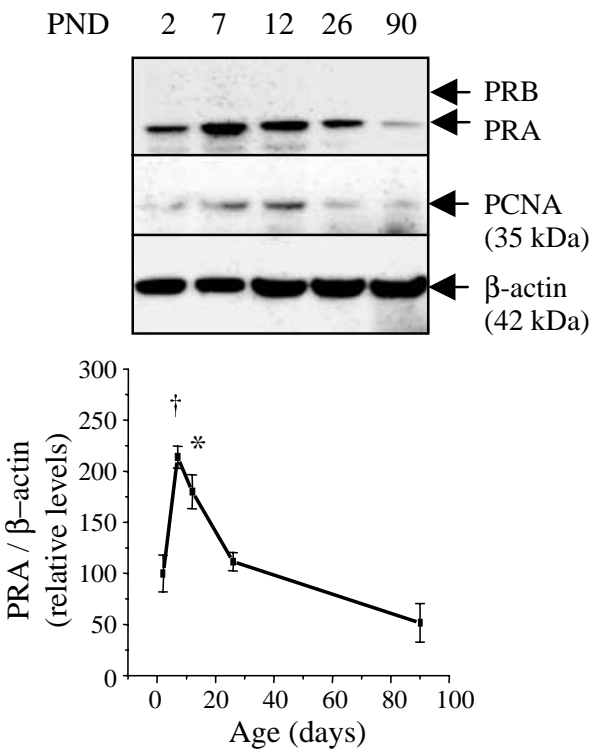

B

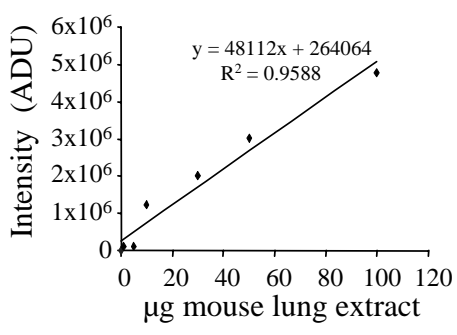

C

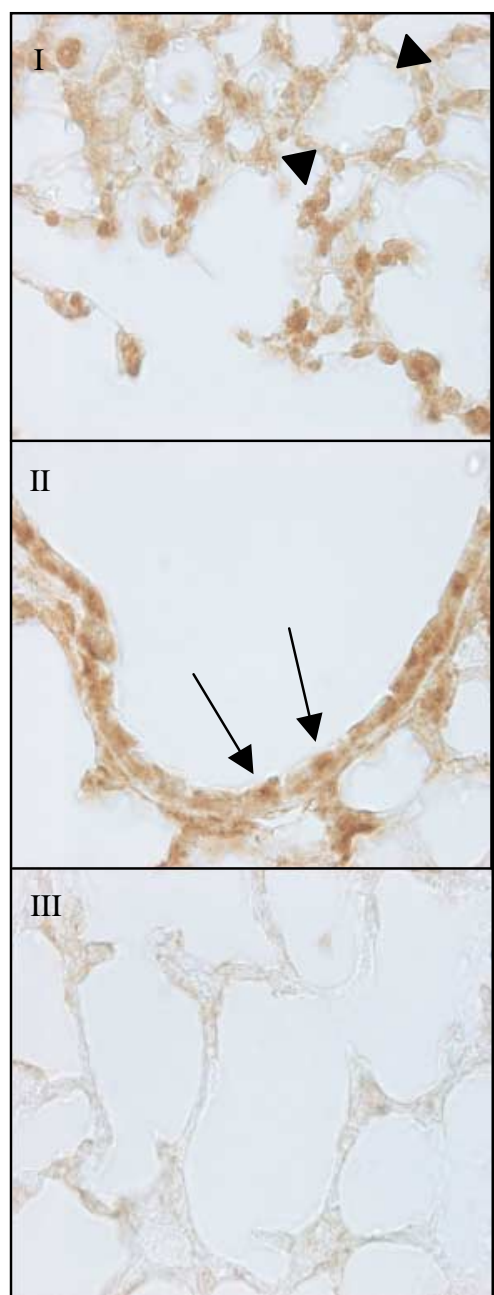

Figure 2 Regulation and cellular localization of PRA protein expression in female mouse lung during postnatal development. (A) Lung tissues from different age female mice were subjected to quantitative Western blot analysis as described in Materials and Methods. Total protein was prepared and analyzed for PR protein isoform and PCNA expression together with the negative control using mouse liver and the positive controls using mouse uterus and fallopian tube. The expression of $\beta$-actin was used as an internal standard to verify equal loading of proteins in all experiments. Five sets of densitometric values obtained from three independent experiments with separate mice for each experiment (five mice in each time point) were normalized by $\beta$-actin and presented as percent of mean \pm S.E.M. relative to PRA protein levels in PND 2 animals. ${ }^{*} P<0 \cdot 05$; ${ }^{\dagger} P<0 \cdot 01$. PND, postnatal days. (B) Standard curve showing a linear relationship between the immunoreactive band intensity and the amount of whole-lung extract protein loaded for mice at PND 7. The equation of the line of best fit was generated by least squares linear regression analysis. (C) Lung tissue sections from 7-day-old female mice stained with PRA/B antibody (I and II) as described in Materials and Methods. No immunostaining of the PRA/B was detected in an adjacent lung section (III) when the synthetic PR blocking peptide was pre-absorbed with excess antigen, confirming the specificity of the PR antibody. Random sections from the lung of three animals provided the same results. Alveolar and bronchial epitheliums are indicated by arrowhead and arrow respectively. All original magnifications: $\times 100$. 
gene necessary for the transition of cells from quiescence to $\mathrm{S}$ phase (Tsurimoto 1999). PCNA was used previously as a reliable marker protein for cell proliferation in mouse lung (Thaete et al. 1989). We demonstrated that the expression pattern of PCNA protein was similar to that of PRA protein in female mice in a parallel experiment. Next, we determined the cellular localization of PR in a 7-day-old mouse lung by immunohistochemical analysis using a mixture of two different polyclonal PRA/B antibodies (c-19+c-20). Positive immunostaining for PR was observed in the alveolar and bronchial epitheliums (Fig. 2C I-II). Comparison of immunostaining between adjacent sections was used to confirm immunoreactive specificity. In adjacent sections of lung stained with either PRA/B antibody and blocking peptides (Fig. 2C III), or PRB antibody (data not shown), no positive signals were detected. Sections from human breast carcinoma as positive controls (data not shown), were run in parallel to reduce discrepancies related to inter-assay variability in immunostaining intensity.

Neither endogenous nor exogenous $\mathrm{P}_{4}$ regulates $\mathrm{PR} A$ protein expression in female mouse lung

Sequential treatment with eCG/hCG to 26-day-old female mice results in induction of ovarian $\mathrm{P}_{4}$ production and further elevates serum $\mathrm{P}_{4}$ levels in vivo (Shao et al. 2003, 2006). To determine whether PRA protein expression is regulated by $\mathrm{P}_{4}$, 26-day-old peripubertal female mice were injected with either $\mathrm{eCG} / \mathrm{hCG}$ or $\mathrm{P}_{4}$. Western blot analysis demonstrated that there was no concomitant change of PRA protein expression in lung (Fig. 3A) when endogenous serum $\mathrm{P}_{4}$ levels were increased (Shao et al. 2006). After treatment with exogenous $\mathrm{P}_{4}$, no significant changes in serum estradiol concentration were apparent (data not shown), whereas a rapid but transient increase in serum $\mathrm{P}_{4}$ concentration was detected at $6 \mathrm{~h}$ followed by a decrease to basal level within $24 \mathrm{~h}$ after $\mathrm{P}_{4}$ treatment (Fig. 3C). Moreover, time-course studies showed that in 26-day-old female mice, treatment with $\mathrm{P}_{4}$ did not affect PRA protein expression in lung (Fig. 3B). Furthermore, timecourse studies also showed that treatment with exogenous diethylstilbestrol $(20 \mu \mathrm{g} / \mathrm{kg}$ per body weight, a non-steroidal synthetic estrogen) (Savu et al. 1979) or dihydrotestosterone $(1 \mathrm{mg} / \mathrm{kg}$ per body weight, a more biologically active androgen) (Gray et al. 1995) did not change PRA protein expression in female mouse lung (data not shown).

\section{Effect of $P R$ antagonist treatment on $P R A$ and $G R$ protein expression in female mouse lung}

$\mathrm{PR}$ antagonists regulate expression of $\mathrm{PR}$ protein isoforms in female reproductive tissues by blocking the actions of $\mathrm{P}_{4}$ in vivo (Donath et al. 2000, Shao et al. 2003, 2006). To determine the effects of PR antagonists on PRA and GR protein expression in mouse lung, 26-day-old female mice, under a gonadotropin regimen, were treated with either RU 486, a PR/GR antagonist, or Org 31710, a specific PR
A
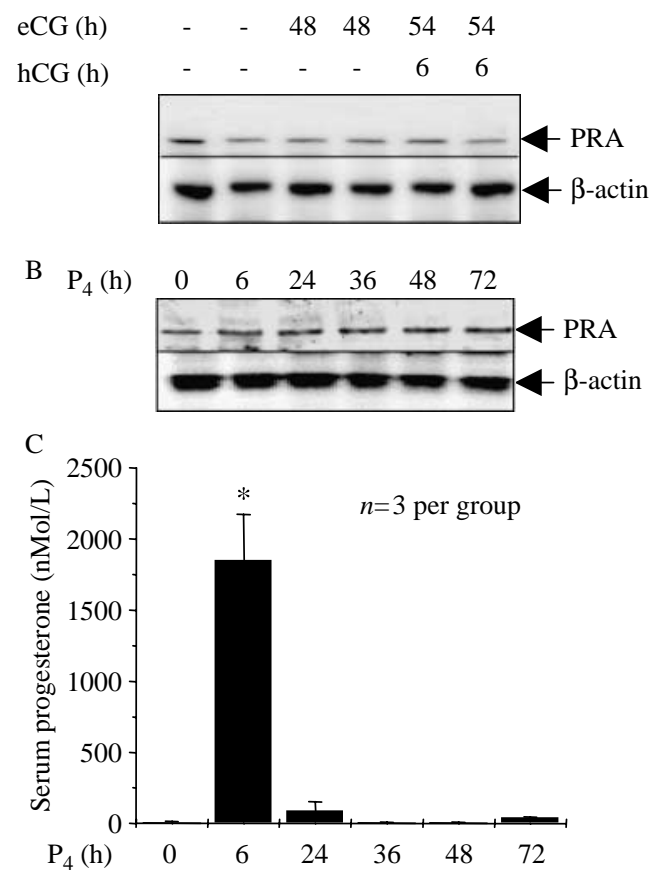

Figure 3 Time-course effects of endogenous and exogenous progesterone $\left(\mathrm{P}_{4}\right)$ on PRA protein expression in female mouse lung. Fresh lungs from 26-day-old female mice treated with eCG and/or (A) hCG or (B) $\mathrm{P}_{4}$ with the indicated times were collected. Protein samples were prepared and subjected to Western blot analysis for detection of PRA protein expression as described in Materials and Methods. The expression of $\beta$-actin was used as an internal standard to verify equal loading of proteins in all experiments (three mice in each experimental group). Corresponding serum $\mathrm{P}_{4}$ levels in trunk blood are shown in (C). The number of mice per group is indicated. Serum $\mathrm{P}_{4}$ concentration was measured in duplicate aliquots of each sample. Values represent the mean \pm S.E.M. *significantly different from untreated animals (time, 0 h), $P<0 \cdot 001$.

antagonist (Kloosterboer et al. 1994). Western blot analysis showed that treatment with RU 486 increased PRA protein expression (Fig. 4A), in parallel with a decrease in GR protein expression (Fig. 4C), without affecting serum $\mathrm{P}_{4}$ concentration (Fig. 4E). However, administration of Org $31710 \mathrm{did}$ not affect either PRA or GR protein expression in the lung (Fig. 4B and D).

Effect of exogenous glucocorticoid dexamethasone treatment on $\operatorname{PRA}$ protein expression in female mouse lung

To determine the effects of glucocorticoids on PRA and GR protein expression in mouse lung, 26-day-old female mice were either vehicle treated or treated with dexamethasone. Western blot analysis indicated that GR protein expression was increased at $6 \mathrm{~h}$ after dexamethasone treatment (Fig. 5A), in association with a decrease in serum $\mathrm{P}_{4}$ concentration (Fig. 5C). Furthermore, dexamethasone treatment in female mice, undergoing a gonadotropin regimen, decreased PRA 
A
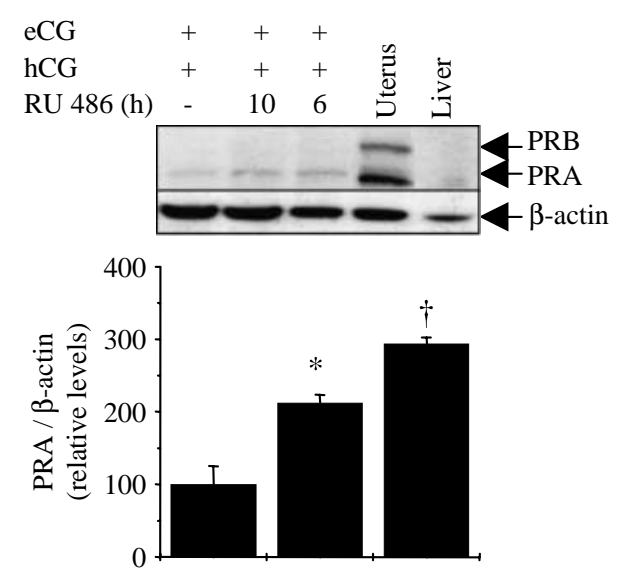

eCG

hCG

RU 486 (h)

C
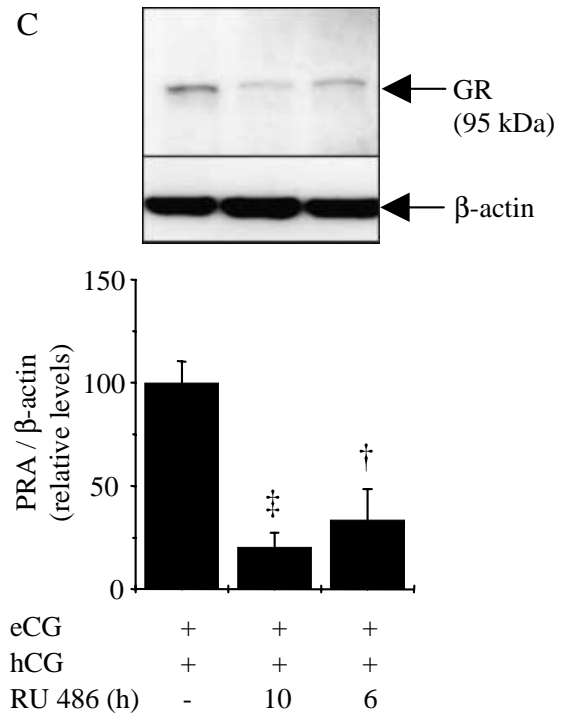

B

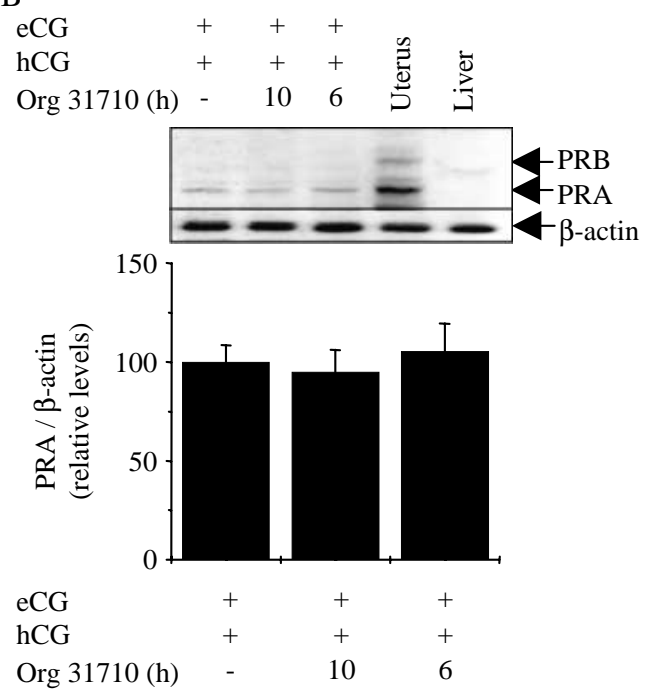

D
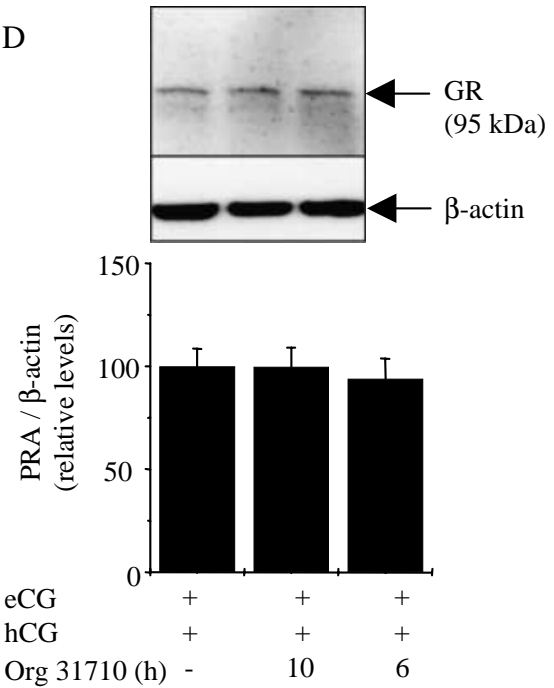

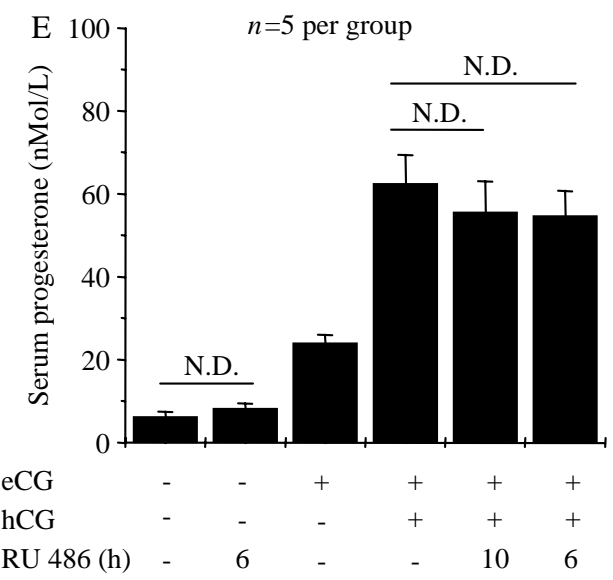



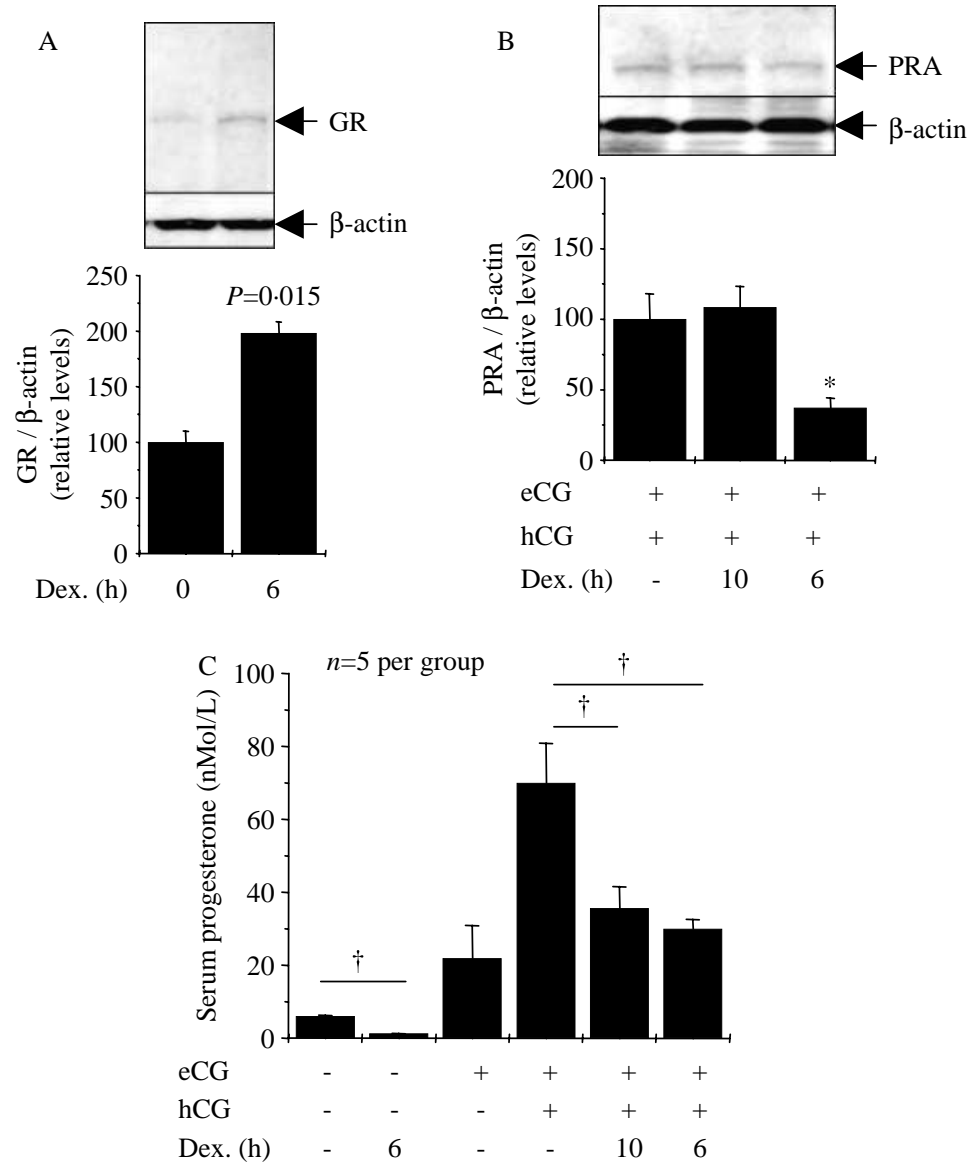

Figure 5 Effect of dexamethasone (Dex) on GR and PRA protein expression in female mouse lung. Twenty-six-day-old female mice treated with Dex for $6 \mathrm{~h}$ without gonadotropin treatment $(\mathrm{A})$ or for 10 and $6 \mathrm{~h}$, given either $4 \mathrm{~h}$ before $\mathrm{hCG}$ or at the same time combined with hCG after 48 heCG treatment (B). After lung tissues were isolated, protein samples were prepared and subjected to Western blot analysis for detection of GR (A) and PRA (B) protein expression as described in Materials and Methods. The expression of $\beta$-actin was used as an internal standard to verify equal loading of proteins in all experiments. All densitometric values for quantitative analysis of PRA protein levels obtained from the individual female mouse lung (five mice in each experimental group) were normalized in relation to $\beta$-actin and presented as percent of mean \pm S.E.M. relative to GR or PRA protein levels in mice treated with eCG/hCG only. ${ }^{*} P<0 \cdot 01$. Corresponding serum $\mathrm{P}_{4}$ levels in trunk blood are shown in (C). The number of mice per group is indicated. Serum $\mathrm{P}_{4}$ concentration was measured in duplicate aliquots of each sample. Values represent the means \pm S.E.M. ${ }^{\dagger} P<0 \cdot 001$.

Figure 4 Effects of RU 486 and Org 31710 on PRA and GR protein expression in female mouse lung. Twenty-six-day-old female mice treated with RU 486 (A) and (C) or Org 31710 (B) and (D) for 10 and 6 h, given either $4 \mathrm{~h}$ before hCG or at the same time combined with hCG after $48 \mathrm{~h}$ eCG treatment. After lung tissues were isolated, protein samples were prepared and subjected to Western blot analysis for detection of PRA (A) and (B) and GR (C) and (D) protein expression as described in Materials and Methods. Mouse uterus and liver were used for the positive and negative controls for PRA/B protein expression. The expression of $\beta$-actin was used as an internal standard to verify equal loading of proteins in all experiments. All densitometric values for quantitative analysis of PRA protein levels obtained from the individual female mouse lung (five mice in each experimental group) were normalized by $\beta$-actin and presented as percent of mean \pm S.E.M. relative to PRA or GR protein levels in mice treated with eCG/hCG only. ${ }^{*} P<0 \cdot 05 ;{ }^{\dagger} P<0 \cdot 01 ;{ }^{\ddagger} P<0 \cdot 001$. Corresponding serum $\mathrm{P}_{4}$ levels in trunk blood are shown in (E). The number of mice per group is indicated. Serum $\mathrm{P}_{4}$ concentration was measured in duplicate aliquots of each sample. Values represent means \pm s.E.M. N.D., no significant difference. 
protein expression (Fig. 5B), depending on injection time. However, dexamethasone treatment decreased serum $\mathrm{P}_{4}$ concentration regardless of injection time (6 and $10 \mathrm{~h}$ ) (Fig. 5C). Our findings demonstrate that dexamethasoneinduced suppression of PRA protein expression is independent of circulating $\mathrm{P}_{4}$ concentration.

\section{$P R A$ physically interacts with GR in mouse lung}

To investigate whether PRA could interact with GR, a co-immunoprecipitation analysis was performed in female mouse lung. Lung tissue extracts from 7- to 26-day-old female mice were subjected to immunoprecipitation with either: anti-GR, anti-PRA/B antibody, anti-PRA/B antibody with specific blocking peptides or anti-PRB antibody. Immunoprecipitates were separated by denaturing electrophoresis and analyzed by Western blot with either the anti-PRA/B (Fig. 6A, left) or anti-GR antibody (Fig. 6A, right). In both the anti-GR and anti-PRA/B precipitates of lung tissue proteins from female mice of different ages, immunoreactive bands for either PRA or GR were revealed. No GR-immunoreactive band was found in immunoprecipitates from protein samples with either anti-PRA/B antibody with specific blocking peptides or anti-PRB antibody (Fig. 6A, right). To further examine the interaction of PRA and GR in vivo, we performed a double-immunofluorescent analysis on lung tissue sections from 26-day-old mice. The majority of PR-positive nuclei co-localized with GR in alveolar epithelia cells, whereas nuclear PR and cytoplasmic GR were detected in bronchial epithelium in both female (Fig. 6B) and male (data not shown) mice.

\section{Discussion}

The molecular basis for the regulation of PR protein isoforms is of great importance for understanding their physiological functions in both reproductive (Shao et al. 2003, 2006) and non-reproductive tissues (Graham \& Clarke 1997). Profiling PR isoform expression and determining their cellular localization in mouse lung would help us in delineating the role of $\mathrm{P}_{4}$ in lung physiology. In this study, we present a detailed demonstration of developmental and hormonal regulation of PRA protein expression in female mouse lung in vivo. More specifically, our results strongly suggest that regulation of PRA protein expression is mediated by the actions of GR in response to glucocorticoids.

The presence of PR in lungs of different species (Giannopoulos et al. 1982, Moser \& Daxenbichler 1982, Bullock et al. 1987, Nielsen et al. 1987, Camacho-Arroyo et al. 1994, 1998, Pasanen et al. 1997, Beyer et al. 2003), is not surprising. However, our experiments do not provide evidence for the existence of PRB in mouse lung. The results, rather, are consistent with the existence of PRA only. First, we obtained the same result when probing blots with different primary PR antibodies in different tissues. Secondly, in order to determine sufficient extraction of receptor from tissue preparation for Western blot procedure, we have used different internal controls (PCNA, $\beta$-actin, and GR). Thirdly, using different molecular techniques, including PCR, Western blot, and co-immunoprecipitation analyses, we confirmed the lack of PRB in mouse lung under very stringent conditions. Uotinen et al. (1999) previously failed to detect PR protein expression by immunohistochemistry in the female adult mice lung. This difference may be explained by the use of different antibodies, experimental techniques, and observation times. Although a specific physiological role for PRA in lung remains to be defined, its identification has provided a potential explanation for the biological actions of $\mathrm{P}_{4}$ in cells where no immunoreactive PRB could be detected.

Considerable evidence has accumulated to indicate that many transcription factors are involved in lung development (Korfhagen \& Whitsett 1997). To further assess the role of PRA as a transcription factor involved in normal lung physiology, we are the first to show in a quantitative manner that the expression of PRA protein in lung is regulated in an age-dependent manner in female mice during postnatal growth and development. At present, the possible function of PRA in lung is not clear. In the first and second weeks of postnatal development, physiological changes take place in the mouse lung, i.e. termination of sac ends on PND 5, alveoli start to form on PND 5 and mature until PND 30 (Burri 1997, Kaplan 2000). Of note, the levels of PRA protein increase and peak at PND 7 when rapid formation of alveoli occurs, whereas decline of PRA protein expression is positively correlated to the postnatal termination of lung development. Moreover, glucocorticoids as a physiological regulator have been implicated in the regulation of postnatal alveolar formation in rodent lung (Burri 1997, Kaplan 2000). In female mice, endogenous serum corticosterone concentrations are very low on PND 5 until PND 15 and significantly increase on PND 25, remaining high during postnatal life compared to that on PND 5 (Morale et al. 1995). In line with previous data, the current study shows that expression of PRA protein is negatively correlated with endogenous serum corticosterone concentrations (Morale et al. 1995). We also show that treatment with dexamethasone, a synthetic glucocorticoid, decreases PRA protein expression in 26-day-old female mice lung, suggesting that glucocorticoids may be involved in the regulation of PRA in mouse lung. Taken together, these observations indicate that PRA may be a significant physiological factor involved in lung postnatal development. On the other hand, the biological effects of PRA expression in lung could be questioned, because it has been reported that mice, lacking either PRA/B or PRA are viable, although exhibiting abnormalities in reproductive systems and function (Curtis \& Korach 2000, Mulac-Jericevic et al. 2000). However, this does not necessarily imply that the respiratory system of these mice is unaffected. Dimerization of the PR isoforms has a potential role as a regulatory step to determine the biochemical properties and biological activity of PRA and 
A

IP
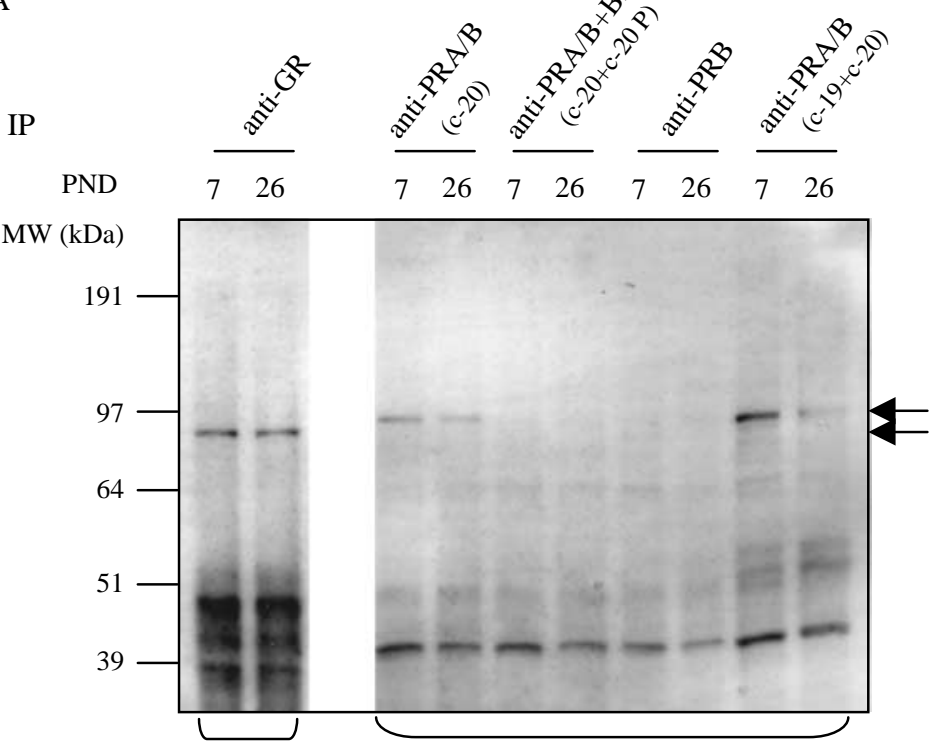

Western anti-PRA/B

anti-GR

$(\mathrm{c}-19+\mathrm{c}-20)$

B
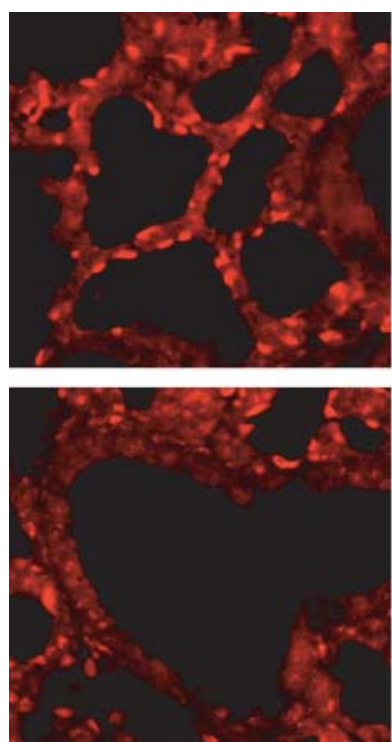

Figure 6 Endogenous PRA physically interacted with GR in mouse lung. (A) Cellular extracts of lung tissues from 7- to 26-day-old female mice were immunoprecipitated with antibodies as indicated. Subsequently, immunoprecipitates were analyzed by Western blot analysis with either anti-PRA/B (left) or anti-GR (right) antibody as described in Materials and Methods. Arrows indicate the presence of PRA and GR protein expression. Running position of molecular weight markers is indicated in $\mathrm{kDa}$ on the left. IP, immunoprecipition; PND, postnatal days; BP, neutralizing synthetic PR peptide. (B) Double-label fluorescence immunohistochemistry for PRA/B and GR in lung from 26-day-old female mice. On the left, PR-immunoreactive nuclei are shown in red (I and IV); in the center panels, GR immunoreactivity is shown in green (II and $\mathrm{V}$ ) and double exposures are shown on the right (III and $\mathrm{VI})$, demonstrating substantial double labeling of both nuclear PR and GR in alveolar epithelium (III), whereas nuclear PR and cytoplasmic GR in bronchial epithelium (VI). Immunostaining is representative of two different experiments with lung tissues obtained from 26-day-old female and male mice. All original magnifications: $\times 40$. 
PRB (Mohamed et al. 1994, McDonnell 1995). Since PRA cannot only dimerize to PRB, but also homodimerize to modulate target cell responsiveness to hormones (Leonhardt et al. 1998) and RU 486 (Mohamed et al. 1994), it is possible that PRA plays a transient role in mouse lung development during the early postnatal period. Future studies will be needed to address the effects of PRA on cell differentiation and function in lung during postnatal development.

Previously, we have shown that PR protein isoform expression in female reproductive tissues including ovary, fallopian tube, and uterus is regulated by gonadotropin treatment that increase endogenous $\mathrm{P}_{4}$ concentration, as well as acute treatment with $\mathrm{P}_{4}$ in female mice (Shao et al. 2003, 2006). The current study demonstrates that neither endogenous nor exogenous $\mathrm{P}_{4}$-regulate $\mathrm{PRA}$ protein expression in lung using the same in vivo experimental model. In addition, a time-course study of both RU 486 and dexamethasone treatment supports the idea that changes in PRA protein expression are independent of circulating $\mathrm{P}_{4}$ concentration in female mouse lung. To our knowledge, this is the first report that demonstrates a functional dissimilarity of $\mathrm{P}_{4}$ and glucocorticoids in the regulation of PRA protein expression in female mouse lung in vivo. Although previous studies have reported that the pure antagonist effect of RU 486 is mediated by the PRA signaling pathway within target cells in vitro (McDonnell \& Goldman 1994, Hurd et al. 1999), RU 486 can interact with both PR and GR (Guettari et al. 1990, McDonnell \& Goldman 1994, Cadepond et al. 1997). We therefore used Org 31710, a specific PR antagonist (Kloosterboer et al. 1994), to distinguish the effects of RU 486 on PRA from the effects on GR. There is no change in PRA protein expression after Org 31710 treatment, suggesting that RU 486 binding to GR regulates PRA protein expression in mouse lung. Furthermore, GR appears to overlap PR cellular distribution in lung (Camacho-Arroyo et al. 1994, Adcock et al. 1996), interacts with estrogen receptors (ER) (Kinyamu \& Archer 2003), and PR has been shown to interact with ER (Uht et al. 1997), suggesting a possibility of interaction between PRA and GR in vivo. The amount of PRA/GR complex detected in PRA and GR immunoprecipitates in this study suggests that PRA and GR are able to crosstalk with each other in response to glucocorticoids through protein-protein interaction in vivo. Interestingly, cellular localization patterns of PR and GR are diverse. Unliganded PR is predominantly nuclear (Smith et al. 1990) whereas unliganded GR resides entirely in the cytoplasm (Hache et al. 1999). Lung is composed of multiple cell types (Amy et al. 1977, Burri 1997) and our immunohistochemistry results show that in the presence of low levels of endogenous corticosterone (Ferrandez \& De la Fuente 1999), PRA is localized predominantly in the nucleus of both alveolar and bronchial epithelia, whereas GR is distributed in either the nucleus of alveolar epithelium or cytoplasm of bronchial epithelium, suggesting that interaction between PRA and GR may differ in a cell type-specific manner. Additional studies will determine whether the interactions of PRA and GR are ligand-dependent using a cell fractionation procedure. Evaluating the significance of the interactions described here requires identification of targets of GR signal activated by glucocorticoids in mouse lung.

Clinically, corticosteroids are the most potent and effective therapy for treatment of chronic inflammatory diseases such as asthma, and they are generally believed to exert their therapeutic benefits by specifically binding to GR, which on activation translocates to the nucleus and either increases or decreases of expression of responsive genes and also suppresses inflammation (Adcock et al. 1996, Umland et al. 2002). It is known that receptor regulation is an important mechanism for modulating target cell responsiveness to hormones. As previously mentioned, several in vitro studies have shown that PRA functions as a strong inhibitor of other steroid receptors including GR (Vegeto et al. 1993, McDonnell et al. 1994). Since the cellular sensitivity to glucocorticoid is directly proportional to GR concentration and the anti-inflammatory activity of GR is mediated by protein-protein interaction (Reichardt et al. 2000), our results suggest that suppression of PRA protein expression by glucocorticoids may affect the regulation and/or modulation of GR levels or activity to enhance lung responsiveness to circulating glucocorticoids, i.e. activation of GR signaling.

In summary, the results of this study document the presence of PRA mRNA and protein in the female mouse lung and demonstrate that PRA protein is expressed and regulated in female mice during postnatal lung development. The relationship between PRA, PCNA protein expression, and alveoli maturation suggests that PRA may play a role in postnatal lung development. However, there was no direct relationship between circulating $\mathrm{P}_{4}$ concentrations and PRA protein expression, suggesting that it is unlikely that $\mathrm{P}_{4}$ is responsible for the regulation of PRA expression in female mouse lung. Moreover, we have shown that exposure to dexamethasone and RU 486, but not Org 31710, in vivo significantly changes PRA protein expression independently of circulating $\mathrm{P}_{4}$ levels. Furthermore, the interaction and co-localization of PRA and GR at physiologically relevant levels depends on the lung cell type, suggesting that further study of such interactions may be relevant to our understanding of the mechanism of action and interaction between PRA and GR signaling pathway in the lung.

\section{Acknowledgements}

We would like to thank Prof. Ola Nilsson, Lundberg Laboratory for Cancer Research, Department of Pathology, Sahlgrenska University Hospital, Göteborg University, for help with lung morphological studies, Emilia Rung for critically reading the manuscript and the Swegene Centre for Cellular Imaging at Göteborg University for the use of imaging equipment. The authors declare that there is no conflict of interest that would prejudice the impartiality of this scientific work. 


\section{Funding}

This work was supported by Grants 10380 and 13550 from the Swedish Medical Research Council to HB, and the Assar Gabrielssons Forsknings Foundation, the Scientific Foundation of Eva och Oscar Ahrens, Wilhelm och Martina Lundgrens, Rudolf och Ellen Maria Mörnes, as well as Hjalmar Svensson and Adlerbertska Research Foundation to RS.

\section{References}

Adcock IM, Gilbey T, Gelder CM, Chung KF \& Barnes PJ 1996 Glucocorticoid receptor localization in normal and asthmatic lung. American Journal of Respiratory and Critical Care Medicine 154 771-782.

Amy RW, Bowes D, Burri PH, Haines J \& Thurlbeck WM 1977 Postnatal growth of the mouse lung. Journal of Anatomy 124 131-151.

Bethea CL \& Widmann AA 1998 Differential expression of progestin receptor isoforms in the hypothalamus, pituitary, and endometrium of rhesus macaques. Endocrinology 139 677-687.

Beyer C, Damm N, Brito V \& Kuppers E 2002 Developmental expression of progesterone receptor isoforms in the mouse midbrain. Neuroreport 13 877-880.

Beyer C, Kuppers E, Karolczak M \& Trotter A 2003 Ontogenetic expression of estrogen and progesterone receptors in the mouse lung. Biology of the Neonate 84 59-63.

Bullock DW, Lamb DJ, Rider VC \& Kima PE 1987 The rabbit progesterone receptor and uteroglobin gene expression. Advances in Experimental Medicine and Biology 230 79-97.

Burri PH 1997 Postnatal development and growth. In The Lung: Scientific Foundations, pp 1013-1026. Eds RG Crystal, JB West, ER Weibel \& PJ Barnes. Philadelphia, PA, USA: Lippincott-Raven.

Cadepond F, Ulmann A \& Baulieu EE 1997 RU486 (mifepristone): mechanisms of action and clinical uses. Annual Review of Medicine $\mathbf{4 8}$ 129-156.

Camacho-Arroyo I, Ruiz A, Gamboa-Dominguez A, Perez-Palacios G \& Cerbon MA 1994 Immunohistochemical localization of intracellular progesterone and glucocorticoid receptors in the rabbit lung. Journal of Endocrinology 142 311-316.

Camacho-Arroyo I, Mendez-Cruz ST, Guerra-Araiza C \& Cerbon MA 1998 Changes in progesterone receptor mRNA content in the rabbit lung during early pregnancy and after sex steroid hormone treatment. Journal of Endocrinology 157 71-74.

Chan YL, Lin A, McNally J, Peleg D, Meyuhas O \& Wool IG 1987 The primary structure of rat ribosomal protein L19. A determination from the sequence of nucleotides in a cDNA and from the sequence of amino acids in the protein. Journal of Biological Chemistry 262 1111-1115.

Condon JC, Hardy DB, Kovaric K \& Mendelson CR 2006 Up-regulation of the progesterone receptor $(\mathrm{PR})-\mathrm{C}$ isoform in laboring myometrium by activation of nuclear factor-kappaB may contribute to the onset of labor through inhibition of PR function. Molecular Endocrinology 20 764-775.

Conneely OM, Maxwell BL, Toft DO, Schrader WT \& O’Malley BW 1987 The $\mathrm{A}$ and $\mathrm{B}$ forms of the chicken progesterone receptor arise by alternate initiation of translation of a unique mRNA. Biochemical and Biophysical Research Communications 149 493-501.

Curtis SH \& Korach KS 2000 Steroid receptor knockout models: phenotypes and responses illustrate interactions between receptor signaling pathways in vivo. Advances in Pharmacology 47 357-380.

Donath J, Nishino Y, Schulz T \& Michna H 2000 The antiovulatory potential of progesterone antagonists correlates with a down-regulation of progesterone receptors in the hypothalamus, pituitary and ovaries. Anatomischer Anzeiger 182 143-150.

Ferrandez MD \& De la Fuente M 1999 Effects of age, sex and physical exercise on the phagocytic process of murine peritoneal macrophages. Acta Physiologica Scandinavica 166 47-53.
Giangrande PH \& McDonnell DP 1999 The A and B isoforms of the human progesterone receptor: two functionally different transcription factors encoded by a single gene. Recent Progress in Hormone Research 54 291-313 (discussion 313-314).

Giannopoulos G, Phelps DS \& Munowitz P 1982 Heterogeneity and ontogenesis of progestin receptors in rabbit lung. Journal of Steroid Biochemistry 17 503-510.

Graham JD \& Clarke CL 1997 Physiological action of progesterone in target tissues. Endocrine Reviews 18 502-519.

Gray K, Eitzman B, Raszmann K, Steed T, Geboff A, McLachlan J \& Bidwell M 1995 Coordinate regulation by diethylstilbestrol of the platelet-derived growth factor-A (PDGF-A) and -B chains and the PDGF receptor alpha- and beta-subunits in the mouse uterus and vagina: potential mediators of estrogen action. Endocrinology 136 2325-2340.

Guettari N, Dufour ME \& Marin L 1990 Effects of the antiglucocorticoid RU 486 on the initiation of ultrastructural type-II cell differentiation in fetal rat lung. Biology of the Neonate $\mathbf{5 8}$ 173-180.

Hache RJ, Tse R, Reich T, Savory JG \& Lefebvre YA 1999 Nucleocytoplasmic trafficking of steroid-free glucocorticoid receptor. Journal of Biological Chemistry 274 1432-1439.

Haggerty CL, Ness RB, Kelsey S \& Waterer GW 2003 The impact of estrogen and progesterone on asthma. Annals of Allergy, Asthma and Immunology 90 284-291 (quiz 291-293, 347).

Hurd C, Nag K, Khattree N, Alban P, Dinda S \& Moudgil VK 1999 Agonistand antagonist-induced qualitative and quantitative alterations of progesterone receptor from breast cancer cells. Molecular and Cellular Biochemistry 199 49-56.

Ilenchuk TT \& Walters MR 1987 Rat uterine progesterone receptor analyzed by $[3 \mathrm{H}] \mathrm{R} 5020$ photoaffinity labeling: evidence that the A and B subunits are not equimolar. Endocrinology 120 1449-1456.

Ishibashi H, Suzuki T, Suzuki S, Niikawa H, Lu L, Miki Y, Moriya T, Hayashi S, Handa M, Kondo T et al. 2005 Progesterone receptor in non-small cell lung cancer - a potent prognostic factor and possible target for endocrine therapy. Cancer Research 65 6450-6458.

Joensuu TK, Ylikomi TJ, Toft DO, Keinanen RA, Kulomaa MS \& Tuohimaa PJ 1990 Progesterone-induced avidin as a marker of cytodifferentiation in the oviduct: comparison to ovalbumin. Endocrinology 126 1143-1155.

Kaplan F 2000 Molecular determinants of fetal lung organogenesis. Molecular Genetics and Metabolism 71 321-341.

Kastner P, Krust A, Turcotte B, Stropp U, Tora L, Gronemeyer H \& Chambon P 1990 a Two distinct estrogen-regulated promoters generate transcripts encoding the two functionally different human progesterone receptor forms A and B. EMBO Journal 9 1603-1614.

Kastner P, Bocquel MT, Turcotte B, Garnier JM, Horwitz KB, Chambon P \& Gronemeyer H $1990 b$ Transient expression of human and chicken progesterone receptors does not support alternative translational initiation from a single mRNA as the mechanism generating two receptor isoforms. Journal of Biological Chemistry 265 12163-12167.

Kinyamu HK \& Archer TK 2003 Estrogen receptor-dependent proteasomal degradation of the glucocorticoid receptor is coupled to an increase in mdm2 protein expression. Molecular and Cellular Biology 23 5867-5881.

Kloosterboer HJ, Deckers GH \& Schoonen WG 1994 Pharmacology of two new very selective antiprogestagens: Org 31710 and Org 31806. Human Reproduction 9 (Suppl 1) 47-52.

Korfhagen TR \& Whitsett JA 1997 Transcriptional control in the developing lung. The Parker B. Francis lectureship. Chest 111 83S-88S.

Kraus WL, Montano MM \& Katzenellenbogen BS 1993 Cloning of the rat progesterone receptor gene $5^{\prime}$-region and identification of two functionally distinct promoters. Molecular Endocrinology 7 1603-1616.

Leonhardt SA, Altmann M \& Edwards DP 1998 Agonist and antagonists induce homodimerization and mixed ligand heterodimerization of human progesterone receptors in vivo by a mammalian two-hybrid assay. Molecular Endocrinology 12 1914-1930.

Lessey BA, Alexander PS \& Horwitz KB 1983 The subunit structure of human breast cancer progesterone receptors: characterization by chromatography and photoaffinity labeling. Endocrinology 112 1267-1274.

McDonnell DP 1995 Unraveling the human progesterone receptor signal transduction pathway. Trends in Endocrinology and Metabolism 6 133-138. 
McDonnell DP \& Goldman ME 1994 RU486 exerts antiestrogenic activities through a novel progesterone receptor A form-mediated mechanism. Journal of Biological Chemistry 269 11945-11949.

McDonnell DP, Shahbaz MM, Vegeto E \& Goldman ME 1994 The human progesterone receptor A-form functions as a transcriptional modulator of mineralocorticoid receptor transcriptional activity. Journal of Steroid Biochemistry and Molecular Biology 48 425-432.

Milne JA 1979 The respiratory response to pregnancy. Postgraduate Medical Journal 55 318-324.

Mohamed MK, Tung L, Takimoto GS \& Horwitz KB 1994 The leucine zippers of $\mathrm{c}$-fos and $\mathrm{c}$-jun for progesterone receptor dimerization: A-dominance in the A/B heterodimer. Journal of Steroid Biochemistry and Molecular Biology 51 241-250.

Morale MC, Batticane N, Gallo F, Barden N \& Marchetti B 1995 Disruption of hypothalamic-pituitary-adrenocortical system in transgenic mice expressing type II glucocorticoid receptor antisense ribonucleic acid permanently impairs $\mathrm{T}$ cell function: effects on $\mathrm{T}$ cell trafficking and $\mathrm{T}$ cell responsiveness during postnatal development. Endocrinology 136 3949-3960.

Moser EH \& Daxenbichler G 1982 Detection of a heat- and acid-stable 'progesterone'-binding protein in the rat lung. FEBS Letters 150 347-353.

Mulac-Jericevic B, Mullinax RA, DeMayo FJ, Lydon JP \& Conneely OM 2000 Subgroup of reproductive functions of progesterone mediated by progesterone receptor-B isoform. Science 289 1751-1754.

Nielsen ST, Conaty JM \& DiPasquale G 1987 Progesterone receptor of adult rabbit lung. Pharmacology 35 217-226.

Pasanen S, Ylikomi T, Syvala H \& Tuohimaa P 1997 Distribution of progesterone receptor in chicken: novel target organs for progesterone and estrogen action. Molecular and Cellular Endocrinology 135 79-91.

Reichardt HM, Tronche F, Bauer A \& Schutz G 2000 Molecular genetic analysis of glucocorticoid signaling using the Cre/loxP system. Biological Chemistry 381 961-964.

Robker RL, Russell DL, Espey LL, Lydon JP, O'Malley BW \& Richards JS 2000 Progesterone-regulated genes in the ovulation process: ADAMTS-1 and cathepsin L proteases. PNAS 97 4689-4694.

Russo LA, Calabro SP, Filler TA, Carey DJ \& Gardner RM 2001 In vivo regulation of syndecan-3 expression in the rat uterus by 17 beta-estradiol. Journal of Biological Chemistry 276 686-692.

Savu L, Benassayag C, Vallette G \& Nunez EA 1979 Ligand properties of diethylstilbestrol: studies with purified native and fatty acid-free rat alpha 1-fetoprotein and albumin. Steroids 34 737-748.

Schneider W, Ramachandran C, Satyaswaroop PG \& Shyamala G 1991 Murine progesterone receptor exists predominantly as the 83-kilodalton ' $\mathrm{A}$ ' form. Journal of Steroid Biochemistry and Molecular Biology 38 285-291.

Shao R, Markstrom E, Friberg PA, Johansson M \& Billig H 2003 Expression of progesterone receptor (PR) A and B isoforms in mouse granulosa cells: stage-dependent PR-mediated regulation of apoptosis and cell proliferation. Biology of Reproduction 68 914-921.
Shao R, Zhang FP, Tian F, Anders Friberg P, Wang X, Sjoland H \& Billig H 2004 Increase of SUMO-1 expression in response to hypoxia: direct interaction with HIF-1alpha in adult mouse brain and heart in vivo. FEBS Letters 569 293-300.

Shao R, Weijdegrd B, Ljungstrom K, Friberg A, Zhu C, Wang X, Zhu Y, Fernandez-Rodriguez J, Egecioglu E, Rung E, et al. 2006 Nuclear progesterone receptor (PR) A and B isoforms in mouse fallopian tube and uterus: implications for expression, regulation and cellular function. American Journal of Physiology. Endocrinology and Metabolism 291 E59-E72.

Smith DF, Faber LE \& Toft DO 1990 Purification of unactivated progesterone receptor and identification of novel receptor-associated proteins. Journal of Biological Chemistry 265 3996-4003.

Taylor AH, McParland PC, Taylor DJ \& Bell SC 2006 The progesterone receptor in human term amniochorion and placenta is isoform C. Endocrinology 147 687-693.

Thaete LG, Ahnen DJ \& Malkinson AM 1989 Proliferating cell nuclear antigen (PCNA/cyclin) immunocytochemistry as a labeling index in mouse lung tissues. Cell and Tissue Research 256 167-173.

Tsurimoto T 1999 PCNA binding proteins. Frontiers in Bioscience $\mathbf{4}$ D849-D858.

Tung L, Mohamed MK, Hoeffler JP, Takimoto GS \& Horwitz KB 1993 Antagonist-occupied human progesterone B-receptors activate transcription without binding to progesterone response elements and are dominantly inhibited by A-receptors. Molecular Endocrinology 7 1256-1265.

Uht RM, Anderson CM, Webb P \& Kushner PJ 1997 Transcriptional activities of estrogen and glucocorticoid receptors are functionally integrated at the AP-1 response element. Endocrinology 138 2900-2908.

Umland SP, Schleimer RP \& Johnston SL 2002 Review of the molecular and cellular mechanisms of action of glucocorticoids for use in asthma. Pulmonary Pharmacology and Therapentics 15 35-50.

Uotinen N, Puustinen R, Pasanen S, Manninen T, Kivineva M, Syvala H, Tuohimaa P \& Ylikomi T 1999 Distribution of progesterone receptor in female mouse tissues. General and Comparative Endocrinology 115 429-441.

Vegeto E, Shahbaz MM, Wen DX, Goldman ME, O'Malley BW \& McDonnell DP 1993 Human progesterone receptor A form is a cell- and promoter-specific repressor of human progesterone receptor B function. Molecular Endocrinology 7 1244-1255.

Wen DX, Xu YF, Mais DE, Goldman ME \& McDonnell DP 1994 The A and $\mathrm{B}$ isoforms of the human progesterone receptor operate through distinct signaling pathways within target cells. Molecular and Cellular Biology 14 8356-8364.

Received 30 March 2006

Received in final form 17 May 2006

Accepted 18 May 2006

Made available online as an Accepted Preprint

9 June 2006 